\title{
Biosorptionof Cadmium Ions ontoGarden Grass
}

\author{
Abbas H. Sulaymon ${ }^{\mathrm{a}}$, Ahmed A. Mohammed ${ }^{\mathrm{b}}$, Tariq J. Al-Musawi ${ }^{\mathrm{c}}$ \\ ${ }^{a}$ Energy Eng. Dept., Baghdad University, Baghdad, Iraq \\ ${ }^{b}$ Environmental Eng. Dept., Baghdad University, Baghdad, Iraq \\ ${ }^{c}$ Corresponding author. Environmental. Eng. Dept., Baghdad University, Iraq.
}

\begin{abstract}
The garden grass was utilized as low cost adsorbent to remove cadmium ions from aqueous solution usingbiosorption. All the experiments were conducted in batch system to investigate the biosorption capacity as well as the effects of $\mathrm{pH}$, temperature, agitation speed, and initial metal concentration on the biosorption efficacy. Fourier Transformation Infrared Spectroscopy analysis was used to find the effectsof functional groups of garden grass in biosorptionprocess. The results showed that the garden grass could be used efficiently to remove cadmium from aqueous solution and up to $85 \%$ of cadmium removal was obtainedat the optimal conditions. The biosorption equilibrium was reached at $60 \mathrm{~min}$ and the maximum biosorption capacity was found to be $17.2 \mathrm{mg} / \mathrm{g}$ for $1 \mathrm{~g}$ dose.Experimental isotherms data well fittedthe Langmuir model. Experimental kinetics data showed that the biosorption process fitted well the pseudo-second-order kinetics model.
\end{abstract}

Keywords: - Garden grass, Cadmium,Biosorption, Equilibrium,Kinetics

\section{INTRODUCTION}

Nowadays, the pollution of environment by heavy metals has become one of the most serious environmental problems (Taha, et al. 2001). This is because they are highly toxic, non-biodegradable, and tend to accumulate causing different health problems in living organisms(Anayurt et al. 2009). The heavy metals enter in tissues through the food chain and accumulate in the body of all living organisms (Doke et al. 2012). Therefore, the elimination of these metals from water and wastewater is important to protect public health. Normally water treatment is not practiced by the industries and as a consequence, many times heavy metals are found in aquatic environment well above the permissible limit. According to World Health Organization, the heavy metals of concern are cadmium, chromium, zinc, copper, lead, mercury, etc. (WHO 1984).

Cadmium is an extremely toxic metal to humans, plants and animals. The major sources of cadmium into the waste streams are electroplating, use of phosphatic fertilizers, smelting, alloy manufacturing, pigments, plastics, batteries and mining (Tsezos 2001; Peavy et al. 1985). Kidney and bone damage have been described to the main problems for patient chronically exposed to cadmium(Barbier et al. 2005). In the present work, cadmium has been chosen as the contaminant in aqueous medium.

There are several methods for the treatment of metal effluents such as precipitation, ion exchange, membrane processes, adsorption and biosorption. Biosorption has been defined as the property of certain biomolecules to bind and concentrate selected ions or other molecules from aqueous solution. As opposed to a much more complex phenomenon of bioaccumulation based on active metabolic transport, biosorption by dead biomass is passive and based mainly on the affinity between the biosorbent and sorbate(Volesky,2007; Diniz et al. 2008). Biosorbent comes under the following categories: bacteria, fungi, algae, industrial wastes and agricultural wastes (Hossain et al. 2012). Among them, agricultural wastes are the potential sources for producing biosorbents as they have low cost and no prominent utilization. A low cost biosorbents are defined as one which is abundant in nature, or is by-product or waste material from another industry. Several studies showed that agricultural waste either in natural or modified is highly efficient for the removal of pollutants. This can be attributed that agricultural wastes are composed of manyeffective functional groups such as lignin, cellulose, alcohols, aldehydes, ketonez, carboxylic, phenolic and ether groups (Lï et al. 2010). In case of removal of cation metals such $\mathrm{Cd}(\mathrm{II}), \mathrm{Pb}$ (II), and $\mathrm{Cu}$ (II), these groups have the ability to some extent to bind heavy metals by donation of an electron pair from these groups to form complexes with the metal ions in solution. Otherwise, the mechanism of sorption process of organic materials has been reported to be very complex and possibility involves the combination of diffusion, chelation, complxation, coordination, or microprecipitation mechanisms depending on the specific biosorbent(Veglio and Beolchini1997).

Grass is an environmentally friendly, low cost, and abundant material after mowing gardens, lawns, and parks. Approximately, ten tons of grass is mower monthly from the gardens of Baghdad University. Often, these quantities were dumped in a municipal solid waste landfill.

Few researches were carried out on the use of gardens grass (GG) as biosorbent. Hossain et al. (2012)were the first researchers whose use GG as biosorbent material. They have reported that the GGexhibits 
an excellentsorption capacity for the removal of copper.Therefore, this study was undertaken to address the problem associated with removal of cadmium from aqueous solutions. The main objectives are: (i) to characterize the physiochemical properties of GG such as specific surface area and functional groups. (ii) toinvestigate the effects of manipulation of some experimental parameters e.g. $\mathrm{pH}$, contact time, biosorbent dose, initial concentration and temperature on thebiosorption capacity of $\mathrm{Cd}(\mathrm{II})$. (iii) tostudy batch biosorption process. (iv) to investigate the isotherm model that can describe the biosorption process. (v) to study the kinetic of cadmium biosorption to understand the mechanism of biosorption onto GG.

\subsection{Adsorbent and chemicals}

\section{MATERIALS AND METHODS}

The GG was collected from the gardens of Baghdad University after mowing. The foreign matters were removed manually from the collected GG. To remove dirt and impurities, the GG washed several times with tap water then with distilled water. The washed GG was cut into small pieces, sundried and then dried in oven at 60 ${ }^{\circ} \mathrm{C}$ for $48 \mathrm{~h}$. The driedmaterial was shredded, grounded into powder. The powdered GG was stored in an opaque and air-tight polyethylene container at room temperature for using in the biosorption experiments with required amounts.The average particle size of powdered grass was measured by sieving method.The Physico-chemical properties of GG were measured at Iraqi Oil and Development Centre and listed in Table (1).

All the chemicals used in this work are analytical grade reagents with deionized water used for solutions preparation. Stock solution $(1000 \mathrm{mg} / \mathrm{L})$ of $\mathrm{Cd}$ (II) was prepared by dissolving the appropriate weight of cadmium nitrate $\mathrm{Cd}\left(\mathrm{NO}_{3}\right)_{2}$ in distilled water and kept in glass container at room temperature. The cadmium nitrate was supplied from FLUKA Company. The desired concentrations were prepared by diluting the stock solution in accurate proportions to different initial concentrations. The concentration of metal was subsequently determined using flame Atomic Absorption Spectrophotometer (AAS, type: SHIMADZU, Model: 7200, JAPAN). The initial $\mathrm{pH}$ of the working solutions was adjusted by addition of $1 \mathrm{~mol} / \mathrm{L} \mathrm{NaOH}$ or $\mathrm{HNO}_{3}$ using a pH meter (WTW, inoLab 720, Germany).

Table (1): Physico-chemical characterization of the powdered grass

\begin{tabular}{ll}
\hline Parameter & value \\
\hline Particle size $(\mathrm{mm})$ & $0.2-0.3$ \\
Surface area $\left(\mathrm{m}^{2} / \mathrm{g}\right)$ & 5.6 \\
Bulk density $(\mathrm{g} / \mathrm{L})$ & 0.48 \\
Porosity $(\%)$ & 60.5 \\
Moisture content $(\%)$ & 1.57 \\
Ash content $(\%)$ & 0.99 \\
\hline
\end{tabular}

\subsection{Biosorption isotherm experiments}

Biosorption of $\mathrm{Cd}(\mathrm{II})$ onto GG was investigated in batch mode sorption equilibrium experiments. The experiments were carried out in $250 \mathrm{~mL}$ sealed conical flasks containing $100 \mathrm{~mL}$ of pre-determined aqueous solution concentration $(1-50 \mathrm{mg} / \mathrm{l})$ and $1 \mathrm{~g}$ of $\mathrm{GG}$, which was continuously shaken at room temperature $(20 \pm 3$ ${ }^{\circ} \mathrm{C}$ ).Before determining optimum $\mathrm{pH}$, the experiments were carried out at the original $\mathrm{pH}$ of cadmium-garden grass solution. Nine flasks were put in a shaker (Edmund Buhler, 7400 Tubingen Shaker-SM 25, Germany) with constant shaking speed $(200 \mathrm{rpm})$ for $3 \mathrm{~h}$ was maintained throughout the experiments. After biosorption, the sorbent was separated from aqueous solution by using filter paper (WHATMAN, No.42, diameter $7 \mathrm{~cm}$ ). The residual concentrations of $\mathrm{Cd}(\mathrm{II})$ were measured by AAS. Biosorption capacity at equilibrium conditions $\left(\mathrm{q}_{\mathrm{e}}\right)$ was calculated using the following equation:

$\mathrm{q}_{\mathrm{e}}=\frac{\left(\mathrm{C}_{\mathrm{o}}-\mathrm{C}_{\mathrm{e}}\right) \mathrm{V}}{\mathrm{m}}$

where, $\mathrm{q}_{\mathrm{e}}$ is the equilibrium biosorption capacity $(\mathrm{mg} / \mathrm{g}) ; \mathrm{C}_{\mathrm{o}}$ and $\mathrm{C}_{\mathrm{e}}$ are the initial and equilibrium adsorbate concentrations in the water $(\mathrm{mg} / \mathrm{L})$, respectively; $\mathrm{V}$ is the volume of used solution $(\mathrm{L})$; and $\mathrm{m}$ is the mass of used adsorbent $(\mathrm{g})$.

The percentage of cadmium removal $(\%)$ was calculated using the following equation:

$\%$ Removal $=\left(\frac{C_{0}-C_{e}}{C_{0}}\right) \times 100$

\subsection{Effect of $\mathrm{pH}$, temperature, agitation speed, and initial concentration}

The effects of $\mathrm{pH}$, temperature, agitation speed, and initial concentration on the biosorptionefficiency were studied as follows. The effect of $\mathrm{pH}$ was performed by shaking sixconical flasks each containing $1 \mathrm{~g}$ of adsorbent dose with $100 \mathrm{~mL}$ of $\mathrm{Cd}$ (II) solution of $50 \mathrm{mg} / \mathrm{l}$ concentration. The $\mathrm{pH}$ of these solutions was adjusted 
to $2,3,4,5,6$, and 7 . ThepH above 7 was excluded due to precipitation of $\mathrm{Cd}(\mathrm{II})$ as hydroxide may occur. The suspension were shaken at room temperature for $3 \mathrm{~h}$ in shaker $(200 \mathrm{rpm})$ and the residual amount of Cd(II) was determined after filtration using AAS.The temperature effect was conducted using $100 \mathrm{~mL}$ of $50 \mathrm{mg} / \mathrm{l}$ initial $\mathrm{Cd}$ (II) concentration. The solutions temperature was $15,25,35,45$, and $55^{\circ} \mathrm{C}$ and the shaken speed was $200 \mathrm{rpm}$ for $3 \mathrm{~h}$. To study the variation of removal efficiency with different initial $\mathrm{Cd}(\mathrm{II})$ concentration, different $\mathrm{Cd}(\mathrm{II})$ concentrations of $10,50,75$ and $100 \mathrm{mg} / \mathrm{l}$ were shaken with $1 \mathrm{~g}$ of garden grass dose. The $\mathrm{pH}$ of solutions was fixed at 4 and the agitation speed was $200 \mathrm{rpm}$ for $4 \mathrm{~h}$.In order to identify the effect of agitation speed variation on the removal efficiency, beaker of 2 liter was filled with 1 liter of $50 \mathrm{mg} / \mathrm{l} \mathrm{metal}$ solution and agitation started before adding the $10 \mathrm{~g}$ of grass, and then samples were taken from 1 to $240 \mathrm{~min}$ to be measured of their remaining concentration. The optimum $\mathrm{pH}$ of removal that obtained from equilibrium isotherm experiments was fixed for metal solution before agitation process started at 100, 150, 200, and $300 \mathrm{rpm}$.

The experimental isotherm data were fitted with the two well-known sorption isotherm models which are Langmuir and Freundlich models. These two models are presented in Table (2). The Langmuir model is the simplest theoretical model for monolayer sorption onto a surface and assumes that all of the sorption sites have equal adsorbate affinity (Bulut and Aydin 2006). The Freundlich isotherm is used for homogenous systems in which the heat of sorption decreases in magnitude with an increasing extent of sorption (Kavitha and Namasivayam 2007). The Freundlich isotherm describes the ratio of the amount of solute that is adsorbed onto a given mass of adsorbent to the concentration of solute in the solution.

\subsection{Kinetic study}

The biosorption kinetic experiments were conducted at concentration of $50 \mathrm{mg} / \mathrm{l}$ and $10 \mathrm{~g}$ of GG in beaker containing 1L of adsorbate solution and agitated in a shaker at a shaking speed of $200 \mathrm{rpm}$. Samples were taken at different time intervals to be measured of their remaining $\mathrm{Cd}$ (II) concentration. The amount of biosorptioncapacityfor each time intervalwas calculated by using eq. (1)

Kinetic models can be helpful for understanding the mechanism of sorption and for evaluating the performance of an adsorbant. In this study, thesorption kinetic data were analyzed by pseudo-first-order and pseudo-second-order kinetic models. Azizian (2004) reported that $\mathrm{k}_{1}$ is not the intrinsic sorption rate constant which was mistakenly reported in the literature. He explained that it is a combination of sorption $\left(\mathrm{k}_{\mathrm{a}}\right)$ and desorption $\left(\mathrm{k}_{\mathrm{d}}\right)$ rate constant. The equations for kinetic models are presented in Table (2). The pseudo-secondorder kinetic model is based on the assumption that the rate of sorption follows second order chemisorptions (Ho and McKay 1999).

Table (2): The equations for the sorption isotherm and kinetics models

\begin{tabular}{|c|c|}
\hline Model & $\begin{array}{lll}\text { Equation } & \text { Linear expression } & \text { Reference }\end{array}$ \\
\hline Langmuir & $\begin{array}{l}\mathrm{q}_{\mathrm{e}}=\frac{\mathrm{q}_{\mathrm{m}} \mathrm{K}_{\mathrm{L}} \mathrm{C}_{\mathrm{e}}}{1+\mathrm{C}_{\mathrm{e}} \mathrm{C}_{\mathrm{e}}}=\frac{1}{\mathrm{q}_{e}}=\frac{\mathrm{C}_{\mathrm{e}}}{\mathrm{q}_{\mathrm{m}} \mathrm{K}_{\mathrm{L}}}+\frac{\mathrm{q}_{\mathrm{m}}}{\mathrm{L}} \text { angmuir }(1918) \\
\mathrm{q}_{\mathrm{e}} \text { is the sorption uptake }(\mathrm{mg} / \mathrm{g}) ; \mathrm{C}_{e} \text { is the equilibrium concentration of the adsorbate } \\
(\mathrm{mg} / \mathrm{mL}) ; \mathrm{q}_{\mathrm{m}} \text { is the maximum amount of the adsorbate per unit weight of the adsorbent } \\
(\mathrm{mg} / \mathrm{g}) ; \mathrm{K}_{\mathrm{L}} \text { is the Langmuir constant and related to the free energy of sorption }(\mathrm{L} / \mathrm{mg})\end{array}$ \\
\hline Freundlich & $\begin{array}{l}\mathrm{q}_{\mathrm{e}}=\mathrm{K}_{\mathrm{F}} \mathrm{C}_{\mathrm{e}}^{1 / \mathrm{n}} \ln \mathrm{q}_{\mathrm{e}}=\ln \mathrm{K}_{\mathrm{F}}+\frac{1}{\mathrm{n}} \ln \mathrm{C}_{\mathrm{e}} \text { Freundlich }(1906) \\
\mathrm{q}_{\mathrm{e}} \text { is the sorption uptake }(\mathrm{mg} / \mathrm{g}) ; \mathrm{C}_{\mathrm{e}} \text { is the equilibrium concentration of the adsorbate } \\
(\mathrm{mg} / \mathrm{L}) ; \mathrm{n} \text { is the Freundlich constant related to sorption intensity }(\mathrm{g} / \mathrm{L}) ; \\
\mathrm{K}_{\mathrm{F}} \text { is the Freundlich constant related to the relative sorption capacity }(\mathrm{mg} / \mathrm{g}) \text {. }\end{array}$ \\
\hline Pseudo-first-order & $\begin{array}{l}\mathrm{q}_{\mathrm{t}}=\mathrm{q}_{\mathrm{e}}\left(1-\mathrm{e}^{-\mathrm{k}_{1} \mathrm{t}}\right) \ln \left(\mathrm{q}_{\mathrm{e}}-\mathrm{q}_{\mathrm{t}}\right)=\ln \mathrm{q}_{\mathrm{e}}-\mathrm{k}_{1} \mathrm{tLagergren}(1898) \\
\mathrm{q}_{\mathrm{t}} \text { is the metal uptake capacity }(\mathrm{mg} / \mathrm{g}) \text { at any time } \mathrm{t}, \mathrm{q}_{\mathrm{e}} \text { is the metal uptake capacity }(\mathrm{mg} / \mathrm{g}) \\
\text { at equilibrium, and } \mathrm{k}_{1} \text { is the observed rate constant of pseudo-first-order kinetic model } \\
(1 / \mathrm{min}) \text {. }\end{array}$ \\
\hline Pseudo-second-order & $\begin{array}{l}\mathrm{q}_{\mathrm{t}}=\frac{\mathrm{k}_{2} \mathrm{q}_{\mathrm{e}}^{2} \mathrm{t}}{1+\mathrm{k}_{2} \mathrm{q}_{\mathrm{e}} \mathrm{t}} \frac{\mathrm{t}}{\mathrm{q}}=\frac{1}{\mathrm{k}_{2} \mathrm{q}_{\mathrm{e}}^{2}}+\frac{\mathrm{t}}{\mathrm{q}_{\mathrm{e}}} \mathrm{Ho} \text { and McKay (2000) } \\
\mathrm{q}_{\mathrm{t}} \text { is the metal uptake capacity }(\mathrm{mg} / \mathrm{g}) \text { at any time } \mathrm{t}, \mathrm{q}_{\mathrm{e}} \text { is the metal uptake capacity }(\mathrm{mg} / \mathrm{g}) \\
\text { at equilibrium, and } \mathrm{k}_{1} \text { is the observed rate constant of pseudo-second-order kinetic model } \\
(\mathrm{g} / \mathrm{mg} \cdot \mathrm{min}) \text {. }\end{array}$ \\
\hline
\end{tabular}

\subsection{Fourier Transfer Infrared Spectroscopy (FTIR) Analysis}

Infrared spectra of powdered raw grass and Cd(II) loaded grass samples were obtained using Fourier transform infrared spectroscope (Model: SHIMADZU 8500S). Normally the spectra are measuring within the range $4000-500 \mathrm{~cm}^{-1}$ (Doke et al. 2012). 


\subsection{FTIR analysis}

\section{RESULTS AND DISCUSSIONS}

FTIR spectra reveals the specific surface functional groups on biosorbent based on the characteristic absorbed energy for each bonds in certain groups (Putra et al. 2009). Fig.1 shows the results of the observed IR absorption frequencies in different regions for GG before and after biosorption of $\mathrm{Cd}(\mathrm{II})$. The results of the FTIR spectrum showed that there were different functional groups detected on the surface of the GG. The broad peak detected in spectra at $3441 \mathrm{~cm}^{-1}$ can be assigned to hydroxyl and amine groups $(-\mathrm{OH}$ and $-\mathrm{NH})$ of alcohols, phenols, and carboxylic acids (Vilar et al. 2009; Chen et al. 2012). The peaks at 3062; 2920, and $2850 \mathrm{~cm}^{-1} \mathrm{can}^{-}$ be assigned to alkyl chains (-C-H) (Arief et al. 2008; Veghetti 2009). The peaks in the region 1720.5 to 1431 $\mathrm{cm}^{-1}$ are due to the presence of, carboxylates, amide, sulfonates and ketones groups $(-\mathrm{C}=\mathrm{O})$ (Arief et al. 2008). The $-\mathrm{C}-\mathrm{O}, \mathrm{C}-\mathrm{C}$ and $-\mathrm{C}-\mathrm{OH}$ stretching vibrations can be attributed to peaks in the region of 1359 to $1041 \mathrm{~cm}^{-1}$. Some bands in the fingerprint regions $(900-750 \mathrm{~cm}-1)$ could be attributed to the aromatic $-\mathrm{C}-\mathrm{H}$ groups (Al-Rub et al. 2006). It was observed from Fig. 1 that after biosorptionCd(II), some peaks were shifted or disappeared and that new peaks were also detected, which suggested that there was a binding process taking place on the surface of the adsorbent. This figure reveals the presence of non-symmetric shifting mainly at spectra range of 2900 to $1750 \mathrm{~cm}^{-1}$ and 900 to $500 \mathrm{~cm}^{-1}$, some peaks are still with no shifting mainly at range of 1700 to 1010 $\mathrm{cm}^{-1}$. So that, it can be conclude that the adsorption capacity of Cd(II) onto GG is influenced by the type and number of functional groups. These results are agreed with the results that observed by Arief (2009) who noted that the adsorption capacity of $\mathrm{Cr}(\mathrm{VI})$ is strongly influenced by type and number of functional groups on the surface of biosorbent.

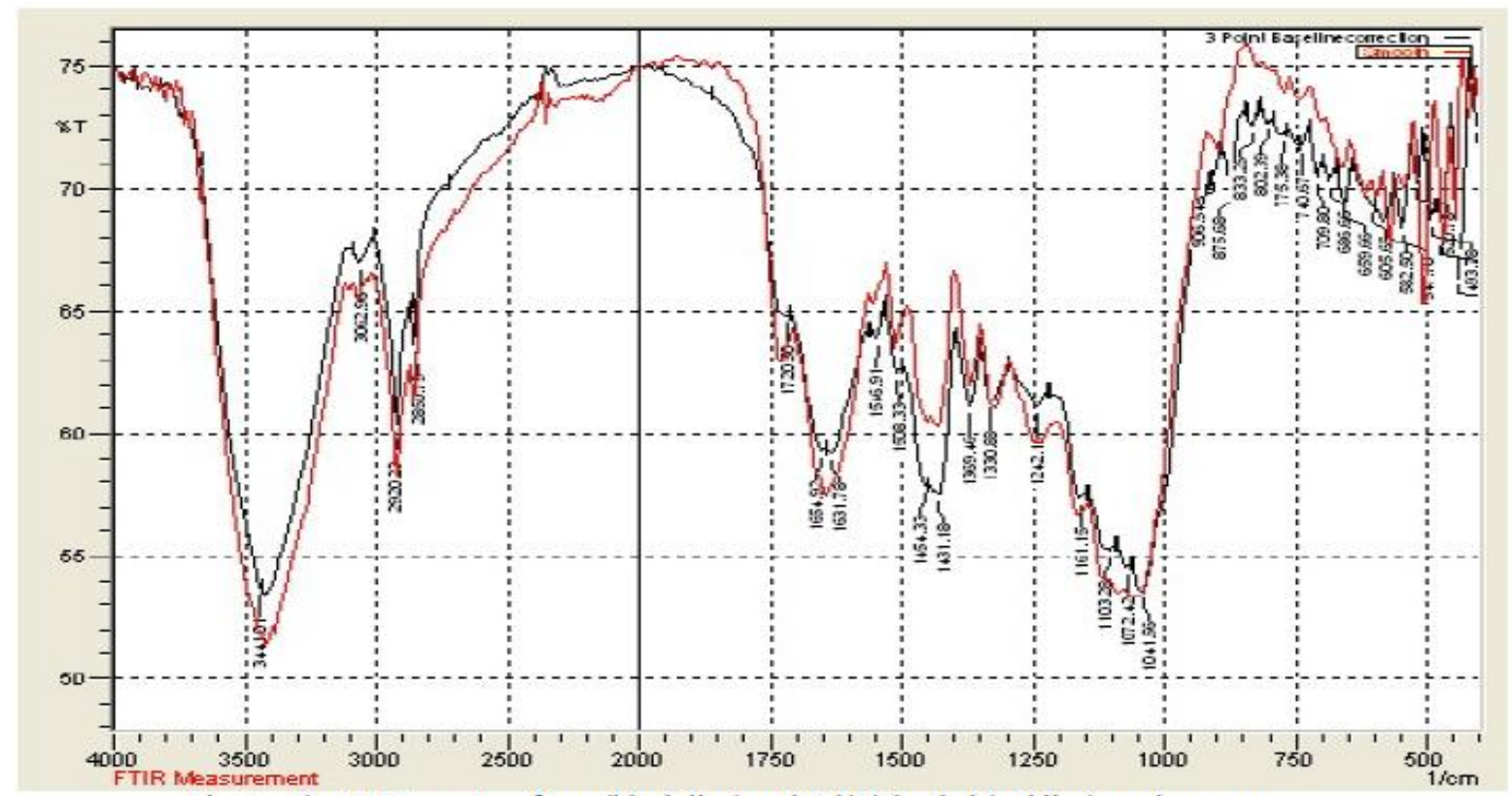

Fig. 1. The FTIR spectra of raw (black line) and Cd(II) loaded (red line) garden grass

\subsection{Effect of pH}

The efficiency of sorption process is $\mathrm{pH}$ dependent due to the variation in $\mathrm{pH}$ value leads to variation of surface properties of adsorbent and the degree of ionization (Aksu and Donmez 2003). The effects of $\mathrm{pH}$, ranging from 2 to 7 , on the biosorption efficiency were studied and the results are depicted in Fig. 2. The results showed that the solution $\mathrm{pH}$ played a significant role in the biosorption process. From this figure, it can be seen that the best $\mathrm{pH}$ value for $\mathrm{Cd}(\mathrm{II})$ removal was around 4 . At lower $\mathrm{pH}$, the active surface sites of the GG were either positively charged (Lu et al. 2008) thus the protons tend to compete with metal ions, or dissociated (Lodeiro et al. 2004 ), which resulted in a decrease in the $\mathrm{Cd}(\mathrm{II})$ removal efficiency. At higher $\mathrm{pH}$, the removal percentage was decreased due to precipitation of metals as hydroxides during the biosorption process. A similar trend was reported for the biosorption of $\mathrm{Pb}(\mathrm{II}), \mathrm{Cd}(\mathrm{II}), \mathrm{Cu}(\mathrm{II})$, and $\mathrm{As}(\mathrm{III})$ removal onto algal biomass (Sulaymon et al. 2013). 


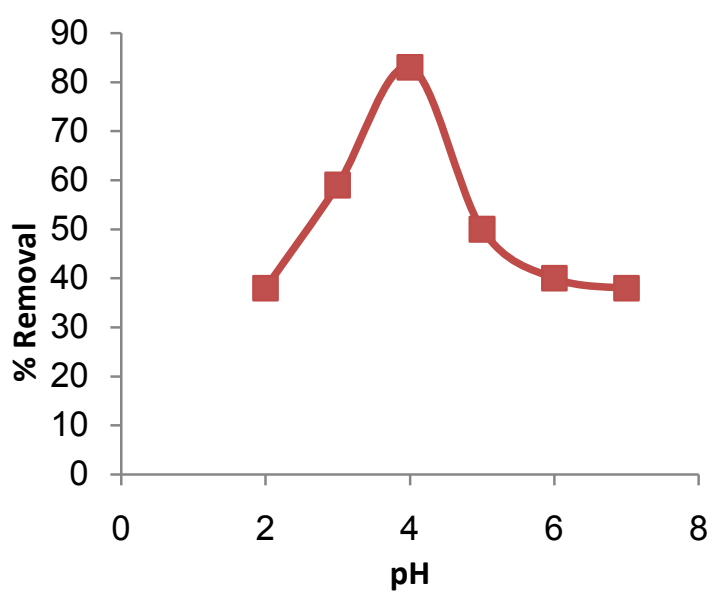

Fig. 2. Effect of $\mathrm{pH}$ on $\mathrm{Cd}(\mathrm{II})$ biosorption

\subsection{Effect of temperature}

The effect of temperature on the Cd(II) removal efficiency has been investigated within a temperature range of 15 to $55^{\circ} \mathrm{C}$ and the results are depicted in Fig. 3. It can be seen that the maximum percentage removal was occurred between $25-45^{\circ} \mathrm{C}$.

The variation of temperature has two major effects on the sorption process. Increasing the temperature is knowing to increase the rate of diffusion of the adsorbate molecules across the external boundary layer and in internal pores of the adsorbent particles as a result of the reduced viscosity of the solution (Almeida et al. 2009; Bulut et al. 2012). In addition, several authors showed that further increases in temperature lead to a decrease the percentage removal. This may be attributed to an increase in the relative desorption of the metal from the solid phase to the liquid phase, deactivation of the biosorbent surface, destruction of active sites on the biosorbent surface due to bond disruption (Saleem et al., 2007; Meena et al., 2005), or due to the weakness of the sorbent active site binding forces and the sorbate species and also between the adjacent molecules of the sorbed phase (Sari and Tuzen 2008). It can be seen from Fig. 3, that the variation of temperature from 25 to 35 ${ }^{\circ} \mathrm{C}$ has minimal effect on the biosorption process, so that experiments can be carried out at room temperature without adjustment.

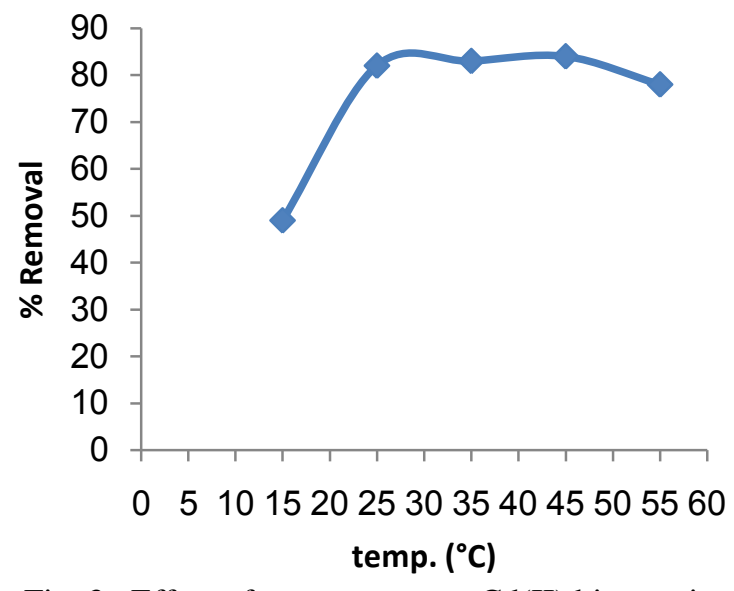

Fig. 3. Effect of temperature on $\mathrm{Cd}(\mathrm{II})$ biosorption

\subsection{Effect of initial conc.}

Fig. 4 shows the results of experiments that measured the effect of variation of initial $\mathrm{Cd}(\mathrm{II})$ concentration on the removal percentage. The results indicated that the percentage removal of Cd(II) was slightly decreased with an increase in the initial Cd(II) concentration from 10 to $50 \mathrm{mg} / \mathrm{l}$, the removal percentage was decreased from 83 to $81 \%$. While a rapid decrease in the percentage removal was observed at initial concentrations ranging between 50 to $100 \mathrm{mg} / \mathrm{l}$. This behavior may be attribute to the decrease in the available sorption sites on the surface area of the adsorbent in the range of $\mathrm{Cd}(\mathrm{II})$ concentration from 50 to $100 \mathrm{mg} / \mathrm{l}$. the same behavior was observed by Li et al. (2012) and Anwar et al. (2010). 


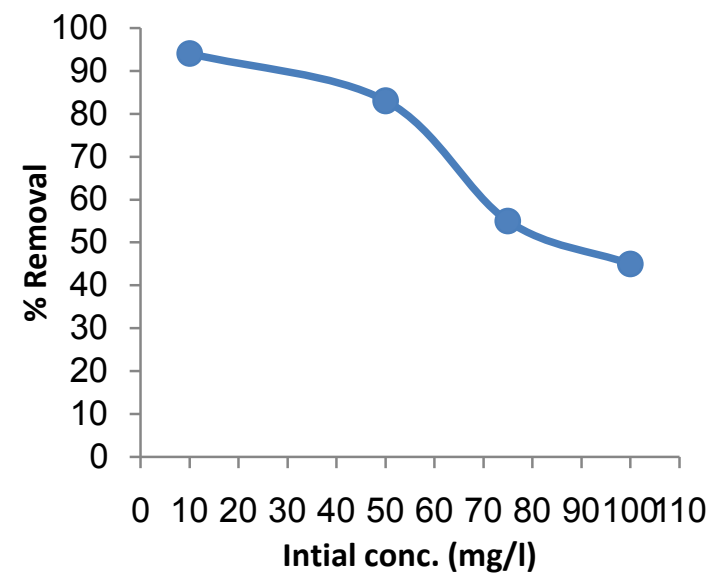

Fig. 4. Effect of initial conc. on Cd(II) biosorption

\subsection{Effect of contact time and agitation speed}

The effects of contact time and agitation speed on the removal efficiency were studied. Fig. 5 is the typical concentration decay curves of $\mathrm{Cd}$ (II) that carried out at different agitation speeds. This figure shows that the removal efficiency increased with an increase in the agitation speed and remained constant after reaching equilibrium time. The optimum agitation speed needed to achieve maximum removal was found to be $300 \mathrm{rpm}$. In addition, Fig. 5 indicates that the Cd(II) removal was rapid at the beginning of contact time and the equilibrium condition gradually reached. This can be attributed to the high availability of surface binding sites onto garden grass while slow rate was attributed to the slow pore diffusion of solute ions into the bulk of the adsorbent (Chen et al. 2012). Vijayaraghavan and Yun (2008) indicated that with appropriate agitation, the mass transfer resistance can be minimized. Additionally, increasing the agitation rate, the diffusion rate of a solute from the bulk liquid to the liquid boundary layer surrounding particles becomes higher due to the enhanced turbulence and the decrease in the thickness of the liquid boundary layer.

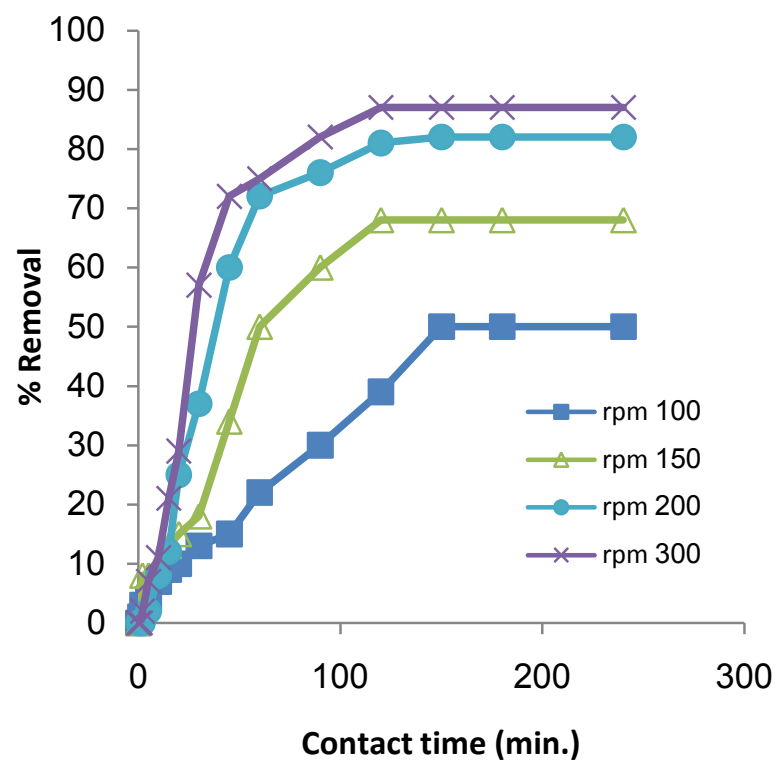

Fig. 5. Effect of contact time on Cd(II) biosorption

\subsection{Isotherm Models}

The biosorption isotherm is a plot that shows the amount of equilibrium uptake vs. the concentration of ion in the solution at equilibrium state (Radnia et al. 2012). This was obtained by the measurement of equilibrium uptake at initial concentration range $1-50 \mathrm{mg} / \mathrm{l}$ as shown in Fig. 6. The values of biosorption capacity increased with the increase of the initial concentration of Cd(II) in the range from 1 to $30 \mathrm{mg} / \mathrm{L}$, then the biosorption capacity reached a plateau. The static biosorption capacity $(17.2 \mathrm{mg} / \mathrm{g})$ of the GG sorbent for Cd(II) was obtained.

Analysis of isotherm data by adapting to different isotherm models is an important step that can be used for design purpose (Doke et al. 2012). Therefore, the experimental equilibrium data were correlated with Langmuir, 
and Freundlich isotherm models. The linearized form of these two models was presented in Table (2). A plot of $\left(\mathrm{C}_{\mathrm{e}} / \mathrm{q}_{\mathrm{e}}\right)$ vs. $\mathrm{C}_{\mathrm{e}}$ should yield a straight line if the Langmuir equation is obeyed by the sorption equilibrium. The slope and the intercept of this line then yield the values of constants $\mathrm{q}_{\mathrm{m}}$ and $\mathrm{K}_{\mathrm{L}}$, respectively. The Freundlich coefficients can be determined from the plot of $\operatorname{lnq}_{\mathrm{e}} \mathrm{vs} \cdot \operatorname{lnC}_{\mathrm{e}}$.

Table (3) shows the constants of the Langmuir and Freundlich isotherms. High $\mathrm{R}^{2}$ value $(0.947)$ of Langmuir model compared to the Freundlich model indicates that the biosorption of $\mathrm{Cd}(\mathrm{II})$ onto garden grass follows the Langmuir isotherm model.

\subsection{Biosorption Kinetic study}

Many applications, such as wastewater treatment and metals purification, need rapid sorption rate and short contact time. The sorption rate is an important parameter used to image the sorption process (Fan et al. 2012). Kinetics of metal ion biosorption determines the rate, which simultaneously calculates the residence time in batch/continuous mode operations and efficiency of an adsorbent (Krishnan and Anirudhan 2003).

Fig. 7 shows the time dependence of the sorption capacity of grass for $\mathrm{Cd}$. It can be seen that the sorption capacity of $\mathrm{Cd}(\mathrm{II})$ increased with the time during the first hour and then a saturation value was reached. It was reasonable to assume that this fast sorption process was due to strong chelation of adsorbent and its smaller diffusion barrier (Fang et al. 2005; Vijayaraghavan and Yun 2008).

Two different kinetic models (pseudo-first-order and pseudo-second-order kinetic models) were used to fit the experimental data. The linear expression of these two models is presented in Table (2). The rate constant, $\mathrm{k}_{1}\left(\min ^{-1}\right)$ and correlation coefficients were calculated from the linear plot of $\ln \left(\mathrm{q}_{\mathrm{e}}-\mathrm{q}_{\mathrm{t}}\right)$ vs. $\mathrm{t}$ and were listed in Table (4). However, linearity of the plots did not necessarily assure the pseudo-first order mechanism. There was a large deviation between the calculated values and the experimental values of sorption capacity. The pseudo-first-order kinetic model was therefore less likely to explain the rate process.

The second-order-kinetic model is based on assumption that the sorption follows second order chemisorption (Ho and McKay 1999). The linear expression of this model is presented in table (2). The rate constant of the pseudo-second-order sorption $\mathrm{k}_{2}(\mathrm{~g} / \mathrm{mg} \cdot \mathrm{min})$ was calculated from the linear plots of $\mathrm{t} / \mathrm{q}_{\mathrm{t}} \mathrm{vs}$. $\mathrm{t}$ and is given in table (4). The straight line with high correlation coefficients $\left(R^{2}>0.99\right)$ was obtained. So that, these results suggest that the second-order-kinetic model can be successfully describes the kinetic of the biosorptionof Cd (II) onto GG.

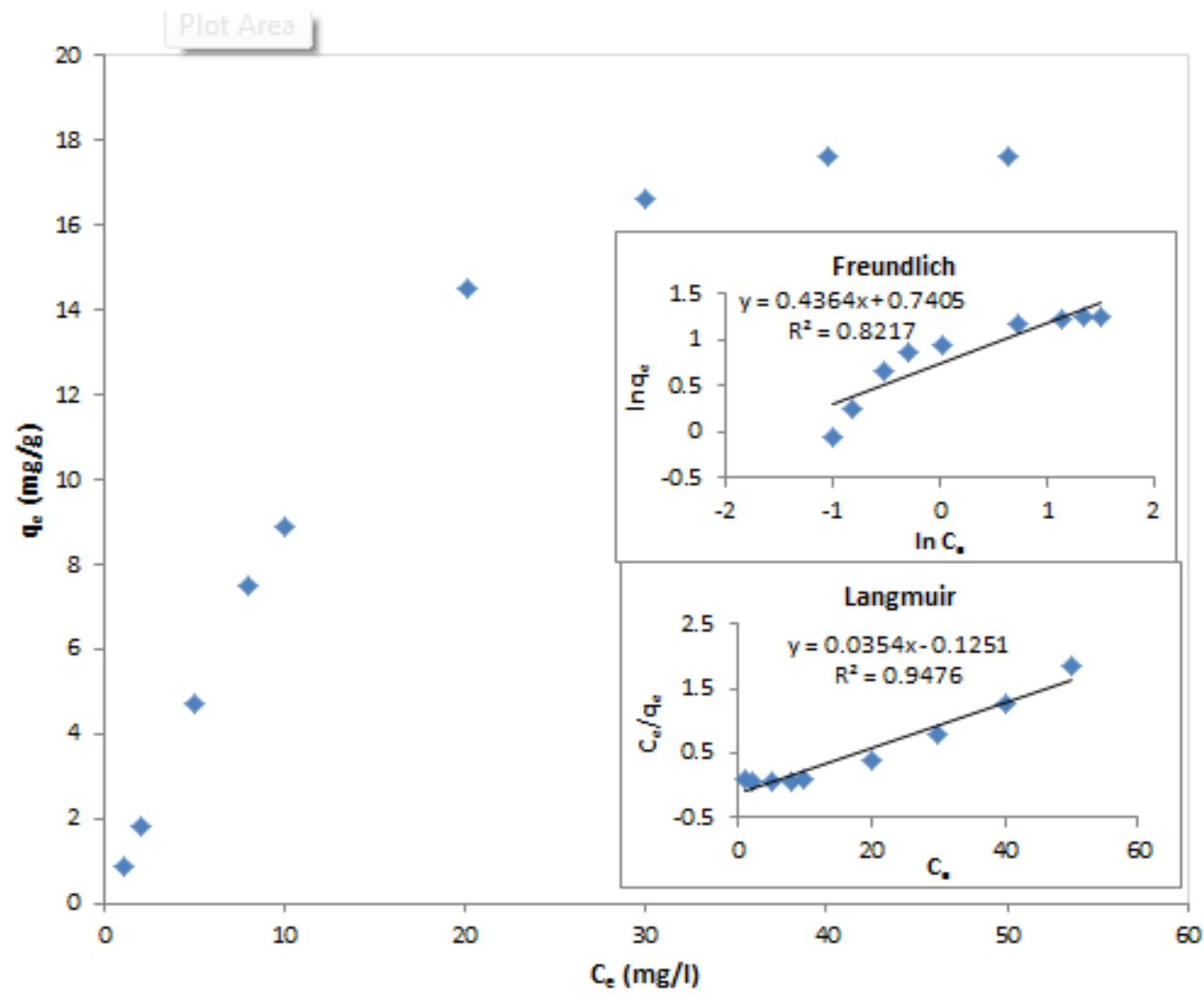

Fig. 6 Biosorptioncapacity of GG for $\mathrm{Cd}(\mathrm{II})$ : concentration $=1-50 \mathrm{mg} / \mathrm{l}$, contact time $3 \mathrm{~h}$ at $200 \mathrm{rpm}, \mathrm{pH}=4.3, \mathrm{GG}$ dose $=1 \mathrm{~g}$, temp.$=$ room temperature 
Table (3) Langmuir and Freundlich isotherm constants for the biosorption of Cd(II) onto grass

\begin{tabular}{|c|c|}
\hline Langmuir isotherm model & Freundlich isotherm model \\
\hline $\mathrm{q}_{\mathrm{m}}=29.25$ & $\mathrm{n}=2.29$ \\
\hline $\mathrm{k}_{\mathrm{L}}=-0.283$ & $\mathrm{k}_{\mathrm{f}}=5.5$ \\
\hline $\mathrm{R}^{2}=0.947$ & $\mathrm{R}^{2}=0.821$ \\
\hline
\end{tabular}

Table (4) Kinetic parameters of Cd(II) biosorption onto GG

\begin{tabular}{|c|c|c|c|c|c|c|}
\hline \multirow[b]{2}{*}{$\begin{array}{c}\mathrm{q}_{\mathrm{eq}}(\exp ) \\
(\mathrm{mg} / \mathrm{g})\end{array}$} & \multicolumn{3}{|c|}{ Pseudo-first-order model } & \multicolumn{3}{|c|}{ Pseudo-second-order model } \\
\hline & $\begin{array}{c}\mathrm{k}_{1} \\
(1 / \mathrm{min})\end{array}$ & $\begin{array}{c}\mathrm{q}_{\mathrm{eq}}(\mathrm{cal} .) \\
(\mathrm{mg} / \mathrm{g})\end{array}$ & $\mathrm{R}^{2}$ & $\begin{array}{c}\mathrm{k}_{2} \\
\text { (g/mg.min) }\end{array}$ & $\begin{array}{c}\mathrm{q}_{\mathrm{eq}}(\mathrm{cal} .) \\
(\mathrm{mg} / \mathrm{g})\end{array}$ & $\mathrm{R}^{2}$ \\
\hline
\end{tabular}

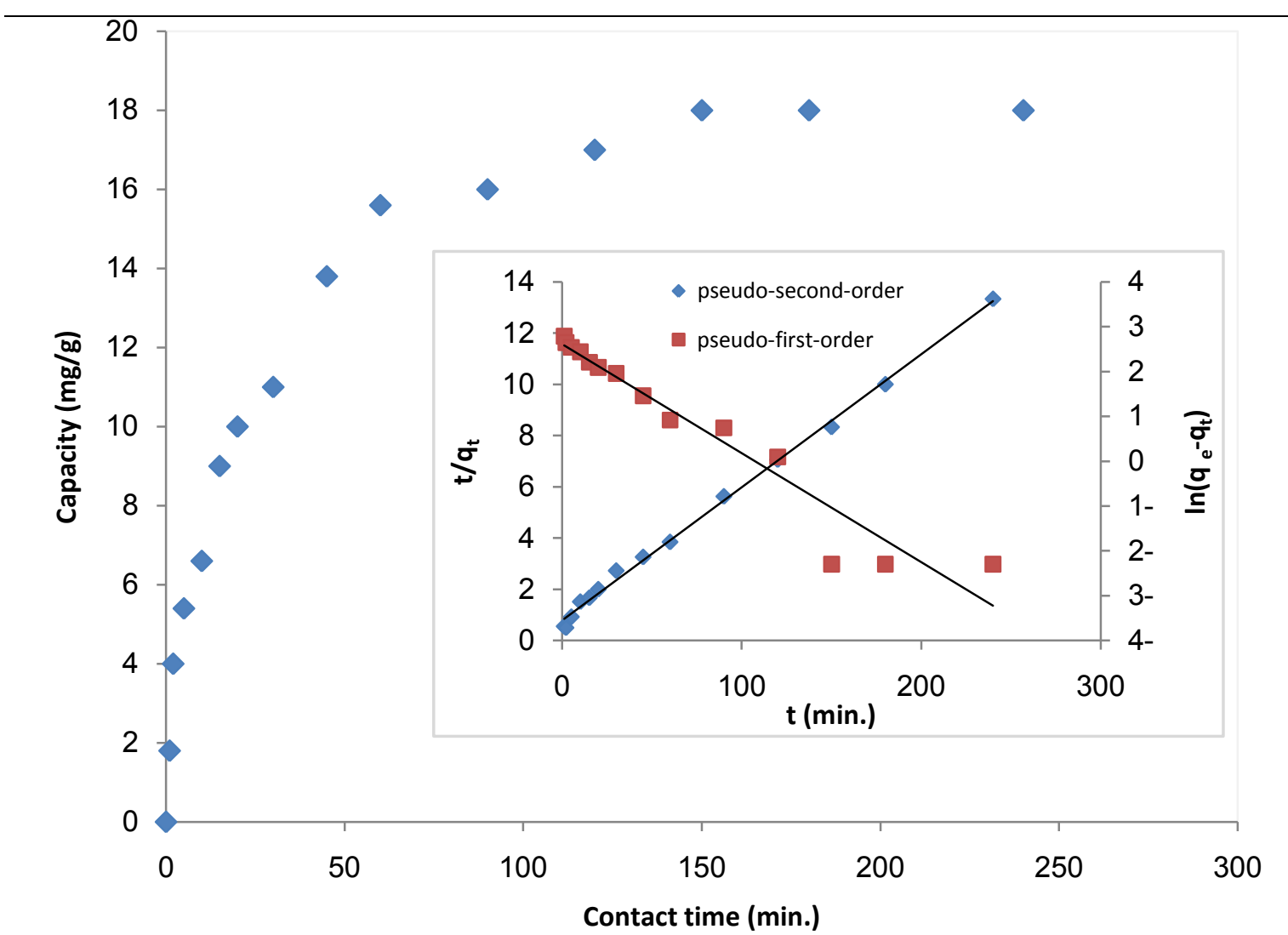

Fig.7Sorption rate of GG sorbent for Cd(II) ions : range of contact time $=1-240$ min, initial Cd(II) conc $=50$ $\mathrm{mg} / \mathrm{l}, \mathrm{pH}=4, \mathrm{GG}$ dose $=10 \mathrm{~g}$, temp.= room temp.

\section{CONCLUSIONS}

This study confirmed that garden grass, a low cost agricultural biosorbent, is a promising biosorbent for the cadmium removal from aqueous solution. The results showed that it was effective to remove cadmium in the acidic medium and at room temperature. The equilibrium biosorption was practically achieved in 60 min. The maximum biosorption capacity obtained was $17.2 \mathrm{mg} / \mathrm{g}$, for $1 \mathrm{~g}$ dose at room temperature. The results indicated that Langmuir model provided the better correlation of experimental data. Pseudo-second-order kinetic model explained the biosorption dynamics process of the cadmium onto garden grass than the pseudo-first-order kinetic model.

\section{REFERENCES}

[1] Aksu Z. and Donmez G., A comparative study on the biosorption characteristics of some yeasts for Remazol Blue reactive dye, Chemosphere, 50 (2003) 1075-1083. 
[2] Almeida C.A.P., Debache N.A., Downsc A.J., Cotteta L., Mello C.A.D., Removal of methylene blue from colored effluents by adsorption on montmorillonite clay, J. Colloid Interf. Sci. 332 (2009) 46-53.

[3] Al-Rub A.A., El-Naas M.H., Ashour I., Al-Marzouqi M., Biosorption of copper on Chlorella vulgaris from single, binary and ternary metal aqueous solutions, process Biochem. 41 (2006) 457-464.

[4] Anayurt, R.A., Sari, A., and Tuzen, M. 2009. "Equilibrium, Thermodynamic and Kinetic Studies on Biosorption of $\mathrm{Pb}(\mathrm{II})$ and $\mathrm{Cd}(\mathrm{II})$ from Aqueous Solution by Macrofungus (Lactariusscrobiculatus) Biomass". Chemical Engineering Journal. 151:255-261.

[5] Anwar, J., Shafique, U., Waheeduz, Z., Salman, M., Dar, A., Anwar, S., Removal of Pb(II) and Cd(II) from water by adsorption on peels of banana, J. Bioresource Technology 101 (6) (2010) 1752-1755.

[6] Arief V.O., Trilestari K., Sunarso J., Indraswati N., Ismadji S., Recent progress on biosorption of heavy metals from liquids using low cost biosorbents: characterization, biosorption parameters and mechanism studies: a review, clean 36 (2008) 937-962.

[7] Azizian S., Kinetic models of sorption: A theoretical analysis, J. colloid Interface Sci. 276 (2004) 47-52.

[8] Barbier O, Jacquillet G, Tauc M, Cougnon M, Poujeol P, 2005, Effect of Heavy metals on, and handling by, the Kidney, Nephron Physiol, 99 , 105-110.

[9] Bulut Y., Aydin H., A kinetic and thermodynamics study of methylene blue adsorption on wheat shells, Desalination 194 (2006) 259-267.

[10] Bulut Y., Gul A., Baysal Z., Alkan H., Asorption of Ni(II) from aqueous solution by Bacillus subtilis, Desalination and Water Treatment 49 (2012) 74-80.

[11] Chen J., Hu Z., Ji R., Removal of carbofuran from aqueous solution by orange peel, Desalination and Water Treatment 49(2012) 106-114

[12] Diniz, V., Weber, M.E., Volesky, B., Naja, G., Column biosorption of lanthanum and europium by sargassum, J. Water Research 47 (2008) 363-371.

[13] Doke K.M., Yusufi M., Joseph R.D., Khan E.M., Biosorption of hexavalent chromium onto wood apple shell: equilibrium, kinetic and thermodynamic studies, Desalination and Water Treatment, 50 (2012) 170179.

[14] Fan H., Li J., Guo M., Fan X., Zhang D., Su Z., and Wang J., 2012, Removal of arsenic from ammoniacal etching waste liquor by 3-(2-aminoethlyamino) propyltrimethoxysilane functionalized silica gel sorbent, Desalination and Water Treatment 50, 51-58.

[15] Fang G., Tan J., Yan X., (2005), An ion-imprinted functionalized silica gel sorbent prepared by a surface imprinting technique combined with a sol-gel process for selective solid-phase extraction of cadmium (II), Anal. Chem. 77 , 1734-1739.

[16] Ho Y.S., McKay G., (1999), Pseudo-second-order model for sorption processes, Process Biochem.34, 451-465.

[17] Hossain M.A., Ngo H.H., Guo W.S., Setiadi T., Adsorption and desorption of copper(II) ions onto garden grass, J. Bioresource Tech. 121(2012) 386-395.

[18] Kavitha D., Namasivayam C., Experimental and kinetic studies on methylene blue adsorption by coir pith carbon ,Bioresour. Technol. 98 (2007) 14-21.

[19] Krishnan K.A., Anirudhan T.S., Removal of Cadmium (II) from aqueous ........, Water SA 29 (2003) 147-156.

[20] Lagergren S., About the theory of so-called adsorption of soluble substances, KungligaSvenskaVeteskapsakademiensHandlingar 24 (1898) 1-39.

[21] Langmuir I., The adsorption of gases on plane surfaces of glass, mica and platinum, J. Am. Chem. Soc. 40 (1918) 1361-1403.

[22] Li C., Li W., Wei L., Research on absorption of ammonia by Nitric acid-modified Bamboo Charcoal at low temperature, 47(2012) 3-10.

[23] Lodeiro, P., Cordero, B., Grille, Z., Herrero, R., Vicente, M.E., Physicochemical Studies of Cadmium (ii) Biosorption by the Invasive Alga in Europe: sargassummuticum, J. Biotechnol. andBioeng. 88(2) (2004), 237-247.

[24] Lu, D., Cao, Q., Li, X., Cao, X., Luo F., Shao, W., Kinetics and equilibrium of Cu(II) Adsorption onto Chemically Modified Orange Peel Cellulose Biosorbents, J. Hydrometallurgy, 2008, http:doi:10.1016/j.hydromet.2008.05.008.

[25] Lü, L., Lu, D., Chen, L., Luo, F., 2010. Removal of Cd(II) by modified lawny grass cellulose adsorbent. Desalination 259 (1-3), 120-130.

[26] Meena, A.K, Mishra, G.K., Rai, P.K., Rajagopal. C., Nagar, P.N., Removal of heavy metal ions from aqueous solutions using carbon aerogel as an adsorbent, J. Hazardous Material 122 (2005) 161-170.

[27] Owoyokun T.O., 2009, Biosorption of Methylene Blue Dye Aqueous Solution on Delonixregia (Flamboyant Tree) Pod Biosorbent, The Pacific Journal of Science and Technology. 
[28] Peavy H.S., Rowe D.R., Techobangalos G., Environmental Engineering, McGraw Hill, New York, NY, 1985, p 38.

[29] Putra E.K., Pranowo R., Sunarso J., Indraswati N., Ismadji S., Performance of activated carbon and bentonite for adsorption of amoxicillin from wastewater : Mechanisms, isotherms and kinetics, Water Res. 43(2009) 2419-2430.

[30] Radnia H., Ghoreyshi A.A., Younesi H., Najafpour G.D., Adsorption of Fe(II) ions from aqueous phase by chitosan adsorbent: equilibrium, kinetic, and thermodynamic studies. Desalination and Water Treatment (50)(2012) 348-359.

[31] Saleem, M., Pirzada, T., Qadeer, R., Sorption of acid violet 17 and direct red 80 dyes on cotton fiber from aqueous solutions, J. Colloids Surf. A: Physicochem. Eng. Asp. 292 (2007) 246-250.

[32] Sari, A., Tuzen, M., 2008, "Biosorption of cadmium (II) from aqueous solution by red algae (Ceramiumvirgatum): Equilibrium, kinetic and thermodynamic studies", J. Hazard. Mat., 157, 448-454.

[33] Sulaymon A.H., Mohammed A.A., Al-Musawi T.J., Competitive biosorption of lead, cadmium, copper, and arsenic ions using algae, Environ .Sci. and Pollut. Res 20 (2013):3011-3023

[34] Taha S., RIcordel S., CIsse I., Dorange G., Heavy metals removal by adsorption onto peanut husks carbon: Characterization, kinetic study and modeling, Sep. Purif. Technol. 24 (2001) 389-401.

[35] Tsezos M., Biosorption of metals: the experience accumulated and the outlook for technology development, Hydrometalurgy 59 (2001) 241-243.

[36] Veglio, F. and Beolchini, F. 1997."Removal of Metals by Biosorption - A Review".Hydrometalluurgy. 44:301-316.

[37] Vijayaraghavan, K. and Yun, Y. S., Competition of Reactive red 4, Reactive orange 16 and Basic blue 3 during biosorption of Reactive blue 4 bypolysulfone-immobilized Corynebacteriumglutamicum. J. Hazardous Material, 153 (2008) 478-486.

[38] Vilar V.J., Botelho C.M., Pinheiro J.P., Domingo R.F., Boaventura R.A., Copper removal by algal biomass: biosorbents characterization and equilibrium modeling, J. Hazard. Mater. 163 (2009) 11131122.

[39] World Health Organization (WHO), Guidelines for drinking water quality, Recommendations, first ed., vol. 1, Geneva, 1984. 